slowed down overnight practically to the edge of death to keep the birdis from starving while they slept. He found, as Weibb found, that they reverted to normal at daybreak when the flowers open and their nectar is again available. Some such physiological change would apparently account for the resistance of the young swifts.

The birds of these two orders (swifts, hummingbirds, goatsuckers and mousebirds) are though't to be fairly primitive as birds go, and they do have a tenacity for life which is remarkable. It is thought that birds evolved comparatively recently from lizard-like reptiles: perhaps the evolutionary adaptations from survival mentioned above are actually atavisms or holdovers from reptilian ancestors, as we know that reptiles can
Survive low temperatures and famine for long periods. These characteristics add some weight to the belief that these birds are quite primitive.

\section{LITERATURE CITED}

LACK, D. and E. LACK. 1955. "The Home Life of the Swifts" in Twentieth Century Bestiary. Simon and Schuster, New York.

LANE, F. W. 1954. Nature Parade Sheridan House, New York.

PEARSON, O. P. 1955. "The Metabolism of Hummingbirds" in "Twentieth Century Bestiary. Simon and Schuster, New York.

PETERSON, R. T. 1947. A Field Guide to the Birds. Houghton, Mifflin, Boston.

POUGH, IR. H. 1957. Audubon West. Bird Guide. Doubleday, New York.

TYLER, W. M. 1940. Life Histories of North American Cuckoos, Goatsuckers, Hummingbirds and their Allies. U. S. National Museum.

WEBB, C. S. 1953. A Wanderer in the Wind. Hutchinson, London.

\title{
Bird Notes from a Farm Shelterbelt
}

\section{By Margaret Belcher, Regina}

Thirty years ago a shelterbelt was planted on our farm at Dilke, with Manitoba maple, ash and Russian poplar spaced four feet apart and oordered with caragana. The ash and ooplar have almost all died out, leaving the maples and caraganas. In this chelterbelt in the past thirty years a haracteristic birdlife has established tself.

The pattern of birdlife here could pe duplicated in practically any shellerbelt in south central Saskatthewan. It is not its novelty that is its attraction-with almost predictable regularity the same birds return each vear to build their nests and raise heir young. Yet, because the farm helterbelt is so compact a unit of a particular type of habitat, and beause the "edge" of the belt of trees $s$ so well suited to birds and to vatching them, the shelterbelt has urprising possibilities for a study of ird behaviour. Even if one is not ngaged in a seriously conducted tudy, it is endlessly interesting to vatch the birds each day when workng in the garden or going about farm hores in the yard.
This year the shelterbelt has had the following resident birds, presumed nesting: Yellow-shafted Flicker (one pair); Eastern Kingbird (probably two pairs); Western Kingbird (two pairs); Least Flycatcher (one pair); Brown Thrasher (probably two pairs); Robin (one pair); Loggerhead Shrike (one pair); Warbling Vireo (probably two pairs); Yellow Warbler (one or two pairs); House Sparrow; Redwinged Blackbird; Baltimore Oriole (one pair); Common Grackle (two pairs); Brown-headed Cowbird; American Goldfinch; Chipping Sparrow (one pair); Clay-colored Sparrow.

The Yellow-shafted Flicker probably did not nest in the shelterbelt, but in a nearby aspen bluff. The male flicker drummed on the combine in the spring: on July 15 five flickers were observed at one time and following that the young were heard often in the shelterbelt calling for food.

The Chipping Sparrow in the shelterbelt was also something of a surprise. After the spring migration of sparrows, I heard the song only once or twice; the other day (July 15), however, I saw the "Chippie" with" 
its characteristic red cap. It surprises one to find a Chipping Sparrow nesting so unobtrusively when one knows them as common and very much in evidence on lawns in cities like Saskatoon and Edmonton. The House Wren on the other hand, is prohably not nesting here this year, although it too has been heard on several occasions. Usually a wren nests in the cattle sheds, and when it does its stuttering song can be heard daily in the shelterbelt.

Only one pair of Baltimore Orioles nested in the shelterbelt this year, and only one pair in 1957; we used to have at least two pairs. A female Oriole found dead in the yard on May 31 may have accounted for the failure of a second pair to nest this year. Recently (July 8) a second dead Oriole was discovered, a male bird brought into the barn at noon by a cat. Had it been killed the day before, we should have thought that the absence of the parent bird explained the plaintive turkey-like "peeps" of two young Orioles which called continuously throughout the day of July 7 . The young Orioles certainly sounded as if they had been deserted, and no adult birds were in evidence. However, a female was observed feeding two young on July 8 , and we recalled then that we had heard the same plaintive peeps last year from young Orioles only just out of the nest. Mrs. Keith Paton, telling of the birds in their shelterbelt at Oxbow, also comments on the "racket" young Orioles make calling to their parents.

Predators in the shelterbelt are rare. Crows do not nest, apparently preferring the bluffs in the fields and pastures. A Magpie attempted to nest this year, but its bulky nest was torn down, and since then it has not even hunted in the shelterbelt as a pair did daily last year.

Why have Redwinged Blackbirds returned to nest in the shelterbelt this year? For years there have been only Brewer's, although I can remember as a child hearing the chorus of Redwings in the trees on early summer mornings. Later, the Redwings must have withdrawn to the more typical habitat of willow-fringed sloughs in the fields. This year they are back. Have they driven away the Brewer's Blackbirds. or simply come in to fill a vacuum left when the
Brewer's, for some reason, stopp nesting here? Some weight is give the latter explanation by a comme in my 1957 notes that Brewer's Blac birds "seem not common this year.

We have never systematical hunted the shelterbelt for nests, fes ing that unless "birdnesting" is e gaged in for some scientific purpo breeding birds should be disturbed little as possible. There are oth ways, of course, of recognizing presence of breeding birds. The di we planted potatoes this spring watched a pair of Grackles carryir nesting materials from the edge of ncarby slough. The female broug slough grasis in her beak on each tri and the male followed her to t slough and back without seeming bring any nesting material. We lat wondered whether the male carric mud unnoticed in his beak. Anoth curious thing that we have notice about the Grackles is the fact th the two pairs are almost always fly ing about together, although the nests are in quite different partis the shelterbelt.

Seasonal singing, of course, al indicates the presence of breedir birds. We suppose, for example, th two pairs of Warbling Vireos hay nested this year because we har heard two Vireos singing all sum mer.

When the young birds begin to ar pear in the last weeks of June p have the final evidence of successf nesting. On June 28, young Grackl and Shrikes appeared, with all tr fuss attending their first venture in the world. Young Orioles ar Thrashers were seen July 7, your Western Kingbirds July 17 . On Ju. 12 the alarm calls of male and fema Redwings drew my attention to your blackbirds in the chokecherries. $N$ less than four adult males had assen bled to join in the warning crie These rilust have been birds of rather late hatch, for the first grou of flocking Redwings was seen in th yard only four days later.

The most interesting nest recor for the year was that of a Hous Sparrow with an apartment in a Wes tern Kingbird's home. One pair Western Kingbirds had a bulky ne: at least four times the size of th other pair's nest. and we realized th: 
hey had tenants when we saw a hale House Sparrow flying into the ree with food.

A farm shelterbeit would lend itelf well to the study and recording $f$ bird song. In addition to the easily ecognized "songs" of the familiar pecies of birds, there are a great rariety of notes, varying with the eason and the purpose of the call. "he spring "okalee" of the Redwing rarely heard now, whereas the arsh "chee" is given repeatedly hroughout the day-to use just one xample. The Brown Thrasher is anther bird with many notes besides he repeated phrases described in ield guides and reminding one of Browning's thrush that "sings each ong twice over."

We are always interested in the Thrasher's second round of song, lastng for a week or ten days later in he season. He began his second eriod of animated singing this year n June 28 and continued to July 7; ast year we heard it also in the last veek in June. Other birds seem to do he same thing. After a period of little ong, the Robin was noticed singing piritedly on July 8 and he continued o sing for almost a week. On July 9 I heard the first Yellow Warbler's ong that I had noticed for some time nd it has been heard for several lays. By contrast, the Warbling Vireo ever stops singing. It is the most onstant singer in the shelterbelt, ersisting in song throughout the day nd throughout the season. I wish I lad kept records of its song this year; cannot remember a day since the rrival of the first Vireo this spring when I have not heard the song. It is o free a singer that the male was oticed to continue its warbling song $s$ it flew in purusuit of the female hortly after their arrival in May.

Our shelterbelt has no winter resilents, only occasional winter visitnts - Black-capped Chickadee, Downy and Hairy Woodpeckers, Norhern Shrike and Pine Grosbeak. pometimes in severe winters Gray Partridge and Sharp-tailed Grouse helter there and come to the oat tacks for feed. A Great Horned Owl which breeds elsewhere on the arm) is occasionally seen sniping rom the tallest trees, and in Decemer, 1956, during what my brother alled the "Killer Blizzard" a Golden
Eagle unexpectedly sheltered there. The most interesting winter visitor was a tiny Boreal Owl (Jan. 2, 1956).

In spring and fall there are migrant thrushes (Swainson's, Gray-cheeked). migrant sparrows (Slate-colored Junco, Tree, Chipping, Harris', White-crowned, White-throated, Lincoln's) and migrant warblers (chiefly Tennessee, Orange-crowned, Myrtle, Blackpoll, Palm). Less commonly we see the American Redstart, and we have one record of the Bay-breasted (May 22, 1954) and one of a Mourning Warbler caught by a cat (Sept. 1, 1952 ); other warblers passing through are missed by not being seen or correctly identified. Of the Kinglets, only the Ruby-crowned has been seen. Pine Siskins are noted as migrants and also as erratic summer visitants.

As summer visitants there come to the shelterbelt Cedar Waxwings, Rose-breasted Grosibeaks (one seen July 30. 1952), and Black-billed Cuckoos. Summer visitants to farm shelterbelits may sometimes provide a real thrill. George Ledingham tells of a SCARLET TANAGER seen at the farm six miles west of Moose Jaw, May 19,1951 , and of a MOCKINGBIRD seen there this year (July 16, 1958). Mrs. Keith Paton, Oxbow, has reported to the Blue Jay a MOCKINGBIRD found dead last summer in the Patons' shelterbelt. Mrs. Paton described it as a greyish bird answering to the description of a Mockingbird in her field guide. She wonders whether a Mockingbird might have nested there recently. "Several years ago," she says, "I found an untidy large nest containing several bluish eggs, in a low bush. At the time, I thought the bird nearby was a Mockingbird but not being so 'birdminded' then as now, I did not bother to get positive proof."

Mrs. Paton went on in her letter to tell about the birdlife in her shelterbelt: this summer they have Catbirds, Brown Thrashers, Eastern Kingbirds, Western Kingibirds (three pairs), Brewer's Blackbirds (which have lost two nests because of Grackles), Wrens, Goldfinches, Yellow Warblers, Baltimore Orioles, Robins (now nesting a second time), Least Flycatchers, and a Black-billed Cuckoo "here as usual, although we've never found a nest." Mrs. Paton's observations and my own illustrate the kind of obser- 
vation that any interested person can make of the birds in a farm shelterbelt. Much more could be done by someone making an intensive life history or behaviour study. The unit of study is so restricted that it may seem entirely insignificant; but it is to be remembered that observations in a limited local area produced Malcolm MacDonald's Birds of Brewery Creek and Gilbert White's Natural History of Selborne.

\section{NEST RECORD CARDS}

Please send your nest records in immediately so that a summary of this year's information may be prepared for the De-. cember issue of the Blue Jay. Cards should be sent to the Saskatchewan Museum of Natural History, Regina.

\section{PROTECTIVE COLORATION OF THE WESTERN MEADOWLARY}

\section{By Ono F. Lick, Davidson, Sask.}

Yesterday, as I sat facing an old window overlooking a shaggy piece of sod, I saw a bird flying downward as if going to alight. By its size, its streaked brownish back and white outer tail feathers, I took it to be a meadowlark. My mind became conscious of cats, so I looked more closely. ready to alert the bird by tapping on the window pane. The sod (I cannot give it the dignified name of lawn) looked very rumpled and tousled, with clumps of old, brown srested wheat grass, fresh green grass underneath and a big patch of prairie beans. I could see no meadowlark. The breeze kept the yellow blossoms of the beans moving. The longer I watched, the more deter mined I became to spot the yellow breasted bird. After watching for fiv minutes, I became bolder and pulle the window curtain aside. Only the did the bird display itself by flyin up. It was an example of remarkiabl protective coloring, the brown of th bird resembling the tufts of dea crested wheat grass and the yellor blossoms of the beans.

I have observed this protective col oring on many occasions. A few year ago I was watching a swarm of fritil lary butterflies amid a patch of dan delions. Walking around among th nodding dandelion heads, scarcel noticeable, was a meadowlark, grab bing off the fritillaries.

\section{MALLARD NESTS IN ABANDONED CROW'S NEST IN ASPEN TRE}

\section{By Frank Roy, Saskatoon}

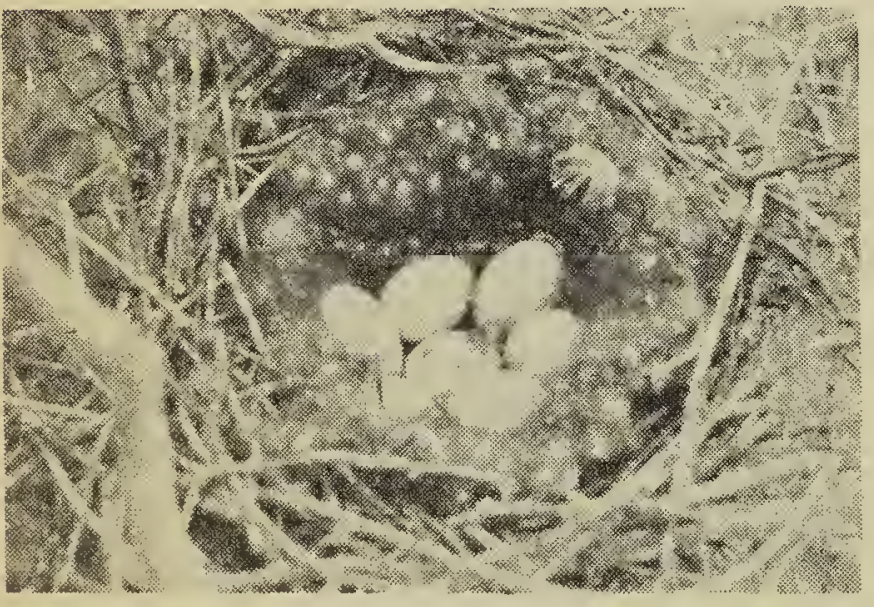

On June 8, 1958, Mr. Bob Darcy, 1340 Colony Street, Saskatoon, reported to me that he had discovered a duck nesting in an abandoned crow's nest in an aspen tree about two miles east of the city on Eighth Street. The crow's nest situated aibout 16 feet up in a 24 -foot aspen, was well preserved and amply line with down. When I observed the ne: on June 8, it contained 7 eggs. Yol on several of the eggs indicated the there had been at least one more eg in the original clutch.

The female Mallard flew off whe we approached the edge of the aspe grove. Three days later, June 11, sh refused to leave the nest until w shook the tree. In each instance sh disappeared through the dense foli age and flew at ground-level unt she was well out of sight. We did no see her return to the nest and won dered whether she landed directly o the nest from above, or whether sh landed at the base of the tree an then flew up to the nest edge. $\mathrm{Ha}$ anyone ever watched a tree-nestin Mallard return to her nest? It woul, be an interesting observation. 